\title{
CONTROL OF VALVE ELECTRIC DRIVE COORDINATES OF AUTOMATED WELDING EQUIPMENT FEED MECHANISMS
}

Goal. Finding ways to improve the quality of operation of the electrode wire feeder in terms of increasing the frequency of undistorted pulse feed with controlled characteristics, in particular its speed, as well as developing methods to simplify the adjustment of regulators of fast-acting electric drive to improve the results of the arc welding and surfacing process. Methodology. In the work, methods of analysis of existing technical solutions were used to increase the speed of operation of electric drives for a specific purpose with the choice of the most rational solution based on the use of the method of synthesis of a control system based on the concept of inverse problems of dynamics with subsequent computer simulation, confirming the adequacy of the applied method of synthesis of high-speed systems. Results. The authors considered the possibilities of increasing the speed of control systems for gearless computerized electric drives in a system with modern designs of valve electric drives for electrode wire feeding systems. A mathematical model of a rectifier motor has been developed with some assumptions that significantly influenced the simulation results. The new possibilities are based on the use of an original synthesis method based on the use of the concept of the inverse problem of dynamics with the subsequent study of the operation of the automatic control system for pulse wire feed, which was performed with aperiodic adjustment of the velocity contour by different methods. This approach made it possible to obtain the necessary laws of electric drive control without the traditional solution of the optimization problem. The developed control system for the electrode wire feed with pulsed motion algorithms provided the required linear movement of the wire at a pulse repetition rate of $100 \mathrm{~Hz}$. The carried out computer simulation of the new control system confirmed the results of the study. It was found that an increase in the pulse time duration over $50 \%$ of the pulse repetition period for given feed frequencies leads to an increase in the wire movement in the pulse, as well as to a decrease in the worked out frequency of the wire linear displacement feed. It was not possible to provide the required wire movement in the impulse feed mode for aperiodic adjustment of the speed loop with a P-controller for the same system parameters. Originality. The development was carried out for a specific application in the electrode wire feed systems of mechanized and automatic equipment for consumable electrode arc welding with obtaining certain algorithms of pulse motion. To effectively solve the complex problem of increasing the frequency of feed pulses with the provision of a displacement step, an original technique of the concept of inverse dynamic problems with confirmation of the result by mathematical modeling by practical results was used. Practical significance. The use of standard settings of the valve electric drive of mechanized and automatic welding equipment provides the frequency of undistorted electrode wire feed in the pulse mode of the feed mechanisms up to $50 \mathrm{~Hz}$. New possibilities of settings made it possible to increase the frequency of wire feed, which makes it possible to raise the quality indicators of welded products - the formation of a welded joint, a decrease in electrode metal losses, an increase in the mechanical properties of a welded joint. References 16, figures 6.

Key words: valve electric drive, automatic control system, adjustment of regulators, pulse wire feed mechanism, welding equipment.

Дослідження показали, щчо використання стандартного налаштування контуру швидкості на симетричний оптимум системи керування механізмом подачі автоматизованого зварювального обладнання забезпечує частоту імпульсної подачі електродного дроту до 60 Гц та покращення якості зварних з'єднань. На основі концепції зворотних задач динаміки в поєднанні з мінімізацією функціоналу миттєвого значення кінетичної енергї̈ синтезовано регулятор швидкості, що дозволило підвищити частоту імпульсів до 100 Гц при відпрацюванні необхідного лінійного переміщення дроту. Це істотно розширюс можливості зварювання і наплавлення. Система керування механізмом подачі дроту реалізована на основі безредукторного вентильного електропривода. Бібл. 16, рис. 6.

Ключові слова: вентильний електропривод, система автоматичного керування, налаштування регуляторів, механізм імпульсної подачі дроту, зварювальне обладнання.

Исследования показали, что использование стандартной настройки контура скорости на симметричный оптимум системы управления механизмом подачи автоматизированного сварочного оборудования обеспечивает частоту импульсной подачи электродной проволоки до 60 Гц и улучшение качества сварных соединений. На основе концепции обратных задач динамики в соединении с минимизацией функционала мгновенного значения кинетической энергии синтезирован регулятор скорости, что позволило повысить частоту импульсов до 100 Гц при отработке требуемого линейного перемещения проволоки. Это существенно расииряет возможности электродуговой сварки и наплавки. Система управления механизмом подачи проволоки реализована на основе безредукторного вентильного электропривода. Библ. 16, рис. 6.

Ключевые слова: вентильный электропривод, система автоматического управления, настройка регуляторов, механизм импульсной подачи проволоки, сварочное оборудование.

Introduction. Mechanized and automatic electric arc welding and surfacing using electrode wire is constantly being improved on the basis of technical and technological innovations [1,2]. One of the ways to improve the quality indicators of welding and surfacing is the use of pulse methods of influence on the arc process, which are carried out both by means of a welding current source [3, 4] and pulse feed of an electrode wire [5, 6]. The relevance of the search for technical solutions that provide an increase in the frequency of wire feed pulses above $60 \mathrm{~Hz}$ for the required range of linear displacement per pulse is due to the task of improving the quality of welding and surfacing [7]. One of the main directions of

(C) V.A. Lebedev, G.V. Zhuk, N.J. Ostroverkhov, A.M. Khalimovskyy 
improving the technology of welding and surfacing with a pulse feed of an electrode wire is the use of high-speed gearless computerized electric drives based on valve electric motors. In this work, on the basis of the concept of inverse problems of dynamics (CIPD) in conjunction with minimization of local functionals of instantaneous values of energies, a synthesis of a control system for a pulsed electrode wire with a valve electric drive (VED) is performed. On the basis of computer simulation of the dynamic processes of the system using MATLAB/Simulink, satisfactory results were obtained, in particular, the speed of operation, which is so necessary for obtaining pulses of electrode wire movement to control the transfer of electrode metal droplets in a controlled mode into the weld pool. A comparative analysis of the results of operation with the control system based on the standard setting of controllers is carried out.

Features of control of wire feeders based on VED. Perspective direction is due to the control of the transfer of electrode metal and associated with it the following main advantages of the process [8]:

- the possibility of a significant improvement in the structure of the weld metal and deposited layer;

- implementation of the task of controlling the shape of the welded joint, the value of reinforcement and penetration;

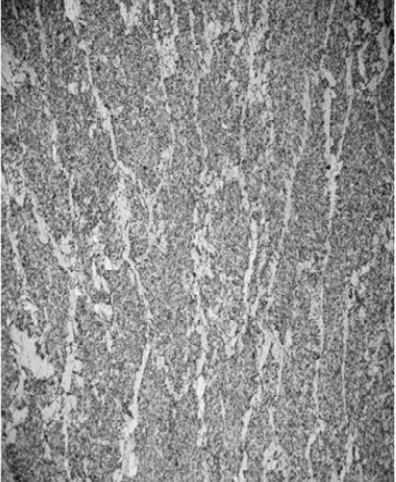

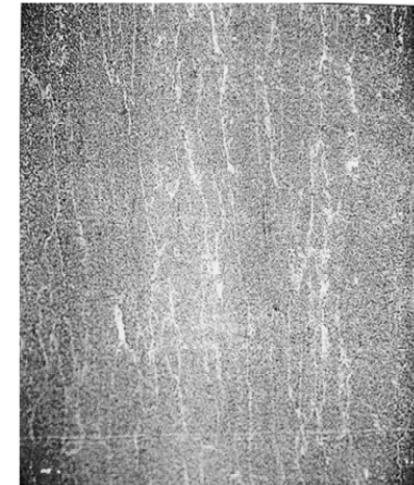

$b$
- reduction of energy and resource consumption.

The implementation of the controlled pulse feed process can be carried out in several ways using different systems. Recently, the most rational technical solution for obtaining a controlled pulse feed is the use of feed mechanisms based on specially developed valve electric motors with a conventional gearless roller propulsion mechanism and a computerized control system [9].

Investigation of the characteristics of the welding process using a valve electric drive with standard settings of the controllers made it possible to determine that the frequency of the pulse feed with a certain step of moving the electrode wire significantly affects the results of surfacing welding in almost all parameters. For an example, partially described in [10], Fig. 1 shows microsections of cross-sections of rollers made on alloy steels at different frequencies of the electrode wire feed.

The analysis of microsections shows that with a pulse feed, the growth of crystals sharply decreases, their disorientation increases, which leads to an increase in the strength and wear resistance of the product being deposited or welded [11].

From the results of the cycle of conducted studies, it is obvious that the wire feed mechanism should have a wide range of wire feed frequencies.

Fig. 1. Microstructures of deposited rollers (X200) at pulse feed frequencies: $a-0 ; b-28 \mathrm{~Hz} ; c-45 \mathrm{~Hz}$

The goal of the work is improving the quality of the wire feed mechanism to improve the characteristics of the arc process by developing a method for adjusting the controller to increase the speed of the speed loop of the electric feed drive.

Application of standard settings of VED of mechanized and automatic welding equipment provides the frequency of undistorted electrode wire feed in a pulse mode of operation up to $60 \mathrm{~Hz}$. An increase in the frequency of wire feeding makes it possible to increase the quality indicators of welded products - the formation of a welded joint, a decrease in electrode metal losses, an increase in the mechanical properties of a welded joint.

Mathematical model of the VED control system. In the study of the automatic control system (ACS) of feeding the electrode wire, the valve electric motor is described by the mathematical model of a DC machine with independent excitation $[15,16]$. A standard ACS has a dual-loop structure of a slave control system, consisting of an internal current control loop with a relay PPT controller and an external speed control loop with a Pcontroller, shown in Fig. 2. Dynamic processes in ACS are described by the following system of equations:

$$
\left\{\begin{array}{l}
M-M_{s t}=J \cdot p \cdot \omega \\
I=\frac{(U-E)}{R_{f} \cdot\left(T_{f} \cdot p+1\right)} \\
U=\frac{\left(I^{*}-K_{1} \cdot I\right) \cdot K_{d r}}{R_{f} \cdot\left(T_{\mu} \cdot p+1\right)} \\
E=c F \cdot \omega \\
M=c F \cdot I \\
I^{*}=\left(\omega^{*}-K_{2} \cdot \omega\right) \cdot K_{g},
\end{array}\right.
$$

where $\omega^{*}, \omega$ are the speed setting and motor rotation speed; $I^{*}, I$ are the current loop setting and motor current; $M$ is the electromagnetic torque of the electric motor; $M_{s t}$ is the moment of resistance on the motor shaft; 
$U$ is the output voltage of the power converter; $E$ is the EMF of the electric motor; $K_{g}$ is the gain of the speed P-controller; $K_{d r}$ is the transmission coefficient of the power converter; $T_{\mu}$ is the time constant of the converter; $K_{1}, K_{2}$ are the current and speed feedback coefficients;
$R_{f}$ is the linear active resistance of the electric motor in a heated state; $T_{f}$ is the time constant of the motor phase; $c F$ is the coefficient of excitation of the electric motor; $J$ is the total moment of inertia, reduced to the motor shaft; $p$ is the Laplace operator.

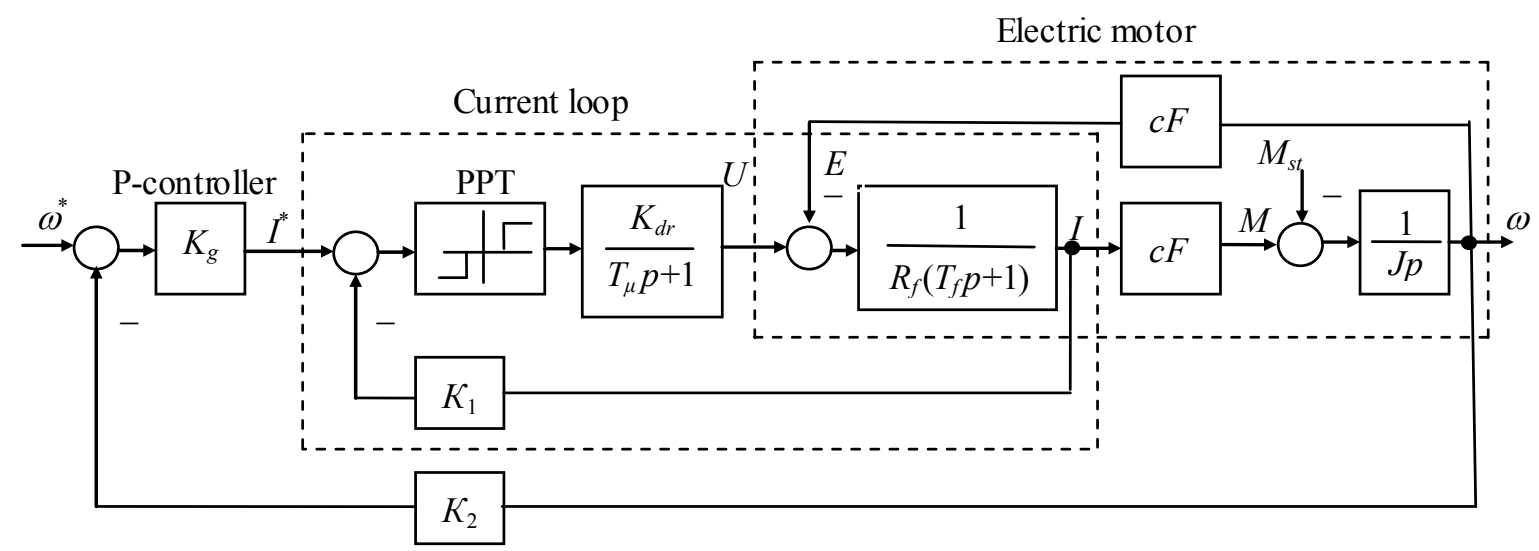

Fig. 2. Block diagram of the automatic speed control system of the valve electric drive of wire feed

Synthesis of the law of VED speed control by the method of inverse problems of dynamics. Analysis of synthesis methods for closed-loop control systems has shown that the use of a non-standard control algorithm synthesized on the CIPD in combination with minimization of local functionals of instantaneous energy values makes it possible to improve the quality of control and the frequency of wire feed. Control laws based on CIPD also provide weak sensitivity to parametric and coordinate disturbances, carry out a dynamic decomposition of an interconnected system and are simple to implement, since they do not contain differentiation operations [12-14]. The advantage of the synthesis method is the definition of control laws without the traditional solution of the optimization problem. The control laws are determined by the type of the differential equation of the object and the type of the differential equation, with the help of which the desired quality of the transient of the closed control loop is set.

According to Fig. 2, the speed loop consists of an optimized internal current loop and an integrating element representing the electromechanical part of the drive. The input of the loop receives the signal of the speed reference $\omega^{*}$. When developing the control law of the speed controller, the inertia of the optimized current loop in the form of a first-order aperiodic link model with a small time constant $T_{1}$ is not taken into account. However, after the synthesis is completed, an analysis is made of its influence on the control quality indicators. After such assumptions, the control object of the speed controller is described by the following first-order differential equation

$$
\dot{\omega}=\frac{c F}{J} I^{*} .
$$

For a first-order object (1), the order of the equation of the desired quality of speed control is also taken to be equal to one

$$
\dot{z}+\alpha_{0} z=\alpha_{0} \omega^{*}
$$

with the provision of first-order astatism and a given quality factor in speed equal to

$$
D_{\omega}^{*}=\alpha_{0} \text {. }
$$

The required duration $t_{n n}$ of the aperiodic transient of the speed is given using a single coefficient of equation (2)

$$
t_{n n} \approx 3 / \alpha_{0} \text {. }
$$

It is necessary to find the control function of the speed controller $I^{*}$ so that the quality of speed control $\omega$ approaches the desired one, given by equation (2). The degree of approximation of the real process to the desired one is estimated by the functional, which characterizes the energy of the first derivative of the kinetic energy normalized to the moment of inertia

$$
G\left(I^{*}\right)=\frac{1}{2}\left[\dot{z}(t)-\dot{\omega}\left(t, I^{*}\right)\right]^{2}
$$

The functional is minimized according to the firstorder gradient law

$$
\frac{d I^{*}(t)}{d t}=-\lambda_{\omega} \cdot \frac{d G\left(I^{*}\right)}{d I^{*}},
$$

where $\lambda_{\omega}>0$ is the constant.

The derivative of the functional taking into account (1) and (2) is equal to

$$
\frac{d G\left(I^{*}\right)}{d I^{*}}=\frac{c F}{J} \cdot(\dot{z}-\dot{\omega}) .
$$
is found

After substituting (6) into (5), the speed control law

$$
\dot{I} *(t)=k_{\omega}(\dot{z}-\dot{\omega}),
$$

where $k_{\omega}=c F \cdot \lambda_{\omega} / J$ is the speed controller gain.

The variable $\dot{z}$ in (7) plays the role of the required acceleration, which is determined in real time from the equation of the desired quality (2) by closing the speed feedback $z=\omega$

$$
\dot{z}=\alpha_{0} \cdot\left(\omega^{*}-\omega\right) \text {. }
$$

The speed control law takes its final form after integrating both sides of equation (7) taking into account (8)

$$
\begin{aligned}
& I^{*}(t)=k_{\omega} \cdot(z-\omega) \\
& z=\alpha_{0} \int\left(\omega^{*}-\omega\right) d t
\end{aligned}
$$


The block diagram of the speed controller built on the basis of (9) is shown in Fig. 3.

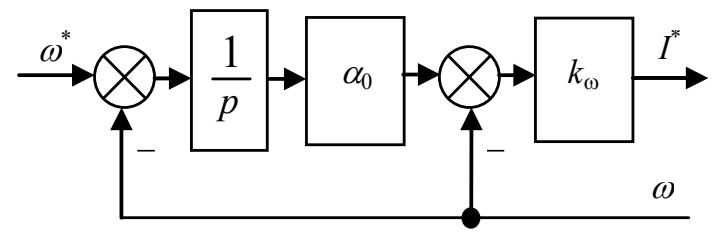

Fig. 3. Block diagram of the speed controller

The speed controller contains only the parameter $\alpha_{0}$ of the desired control law and does not contain the parameters of the control object, which is typical for classical control laws.

Closed loop speed equation

$$
\ddot{\omega}+\frac{c F}{J} \cdot k_{\omega} \cdot \dot{\omega}+\frac{c F}{J} \cdot k_{\omega} \cdot \alpha_{0} \cdot \omega=\frac{c F}{J} \cdot k_{\omega} \cdot \alpha_{0} \cdot \omega^{*},(
$$

obtained after substituting control law (9) into the object equation (1), shows that closed-loop system (10) is stable even with an unlimited increase in the gain of the speed controller $k_{\omega} \rightarrow \infty$. According to the Hurwitz stability criterion, the coefficients of equation (10) are positive

$$
\frac{c F}{J} \cdot k_{\omega}>0 ; \quad \frac{c F}{J} \cdot k_{\omega} \cdot \alpha_{0}>0 \text {. }
$$

An important task is to determine the properties of the speed loop at finite values of the controller gain. According to the transfer function of the speed open loop obtained on the basis of (10)

$$
W(p)=\frac{c F \cdot k_{\omega} \cdot \alpha_{0} / J}{p \cdot\left(p+c F \cdot k_{\omega} / J\right)},
$$

the speed loop has a given first-order astatism, as well as a speed quality factor equal to the given one (3)

$$
D_{\omega}=D_{\omega}^{*}=\alpha_{0} \text {. }
$$

This ensures the degree of approximation of the real transient of the speed to the desired process specified by (2), with moderate gain of the speed controller $k_{\omega}$.
The estimation of the influence of the unaccounted inertia of the current loop with a small time constant $T_{1}$ on the dynamic properties of the speed loop is carried out using the characteristic equation of the closed-loop system obtained similarly to (10)

$$
T_{1} \cdot T_{0} \cdot p^{3}+T_{0} \cdot p^{2}+k_{\omega} \cdot p+k_{\omega} \cdot \alpha_{0}=0,
$$

where $T_{0}=J / c F$ is the time constant of the controlled object.

For the stability of the speed loop according to (13), the condition $\alpha_{0}<\left(1 / T_{1}\right)$ must be satisfied. Thus, the inertia of the current loop limits the desired speed of the speed loop.

Investigation of the VED control system. The research was carried out by modeling in the MATLAB/Simulink software package. To assess the efficiency of the speed control system of the valve electric drive of the wire feeder, a comparative analysis of the simulation results of the proposed system with a controller (9) and an ACS with a speed P-controller was carried out. The value of the P-controller gain $K_{g}=8.75$ was obtained when the speed loop was tuned to an aperiodic process. When simulating a two-circuit ACS, the following values of the parameters of the structural diagram were taken: $T_{f}=0.5 \mu \mathrm{s} ; R_{f}=0.9 \Omega ; c F=1 \mathrm{~V} \cdot \mathrm{s}$; $J=0.001 \mathrm{~kg} \cdot \mathrm{m}^{2} ; K_{1}=1.94 ; K_{2}=0.25$. The current loop of each of the systems under consideration contains a PPT with a dead zone of $0.5 \mathrm{~V}$. The voltage at the output of the power converter is $U=24 \mathrm{~V}$.

The simulation results of the current loop with a sinusoidal reference signal with a frequency of $100 \mathrm{~Hz}$ for the adopted settings are shown in Fig. 4. Analysis of the simulation results of the current loop for the reference signal $I^{*}$ shows the satisfactory dynamics of its development.
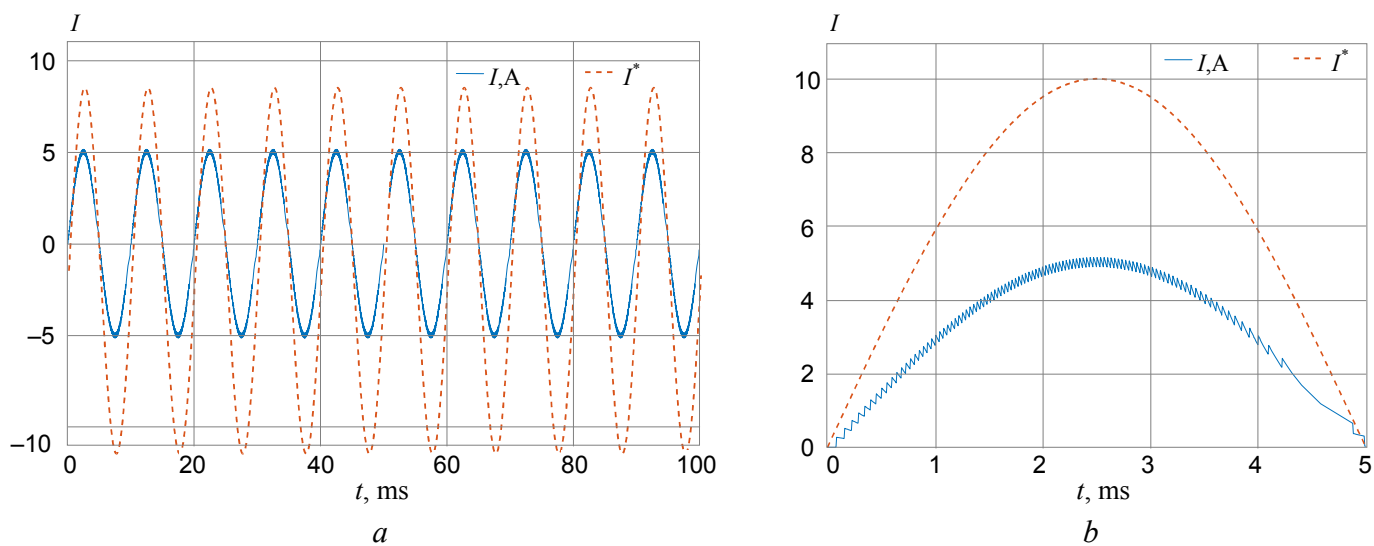

Fig. 4. Results of simulation of transients of the system current loop

The results of modeling the transients of both systems with a stepwise reference signal are shown in Fig. 5. Curves $\omega_{1}$ correspond to a system with a controller (9), and $\omega_{2}-$ to a system with a P-controller. Comparative analysis of the graphs of transients of the speed of systems (Fig. 5, $a$ at $\alpha_{0}=500$; Fig. 5,b at $\alpha_{0}=1700$ ) confirms the dependence of the time of the transient on the value of the parameter $\alpha_{0}$. Increasing this parameter at a constant value $k_{\omega}=100$ shortens the transient time. Based on the simulation results, the maximum value of the parameter $\alpha_{0}=1700$ was determined for the aperiodic adjustment of the speed loop. With an increase in the value of this parameter, at a jump in the speed reference, overshoot appears in the system. 

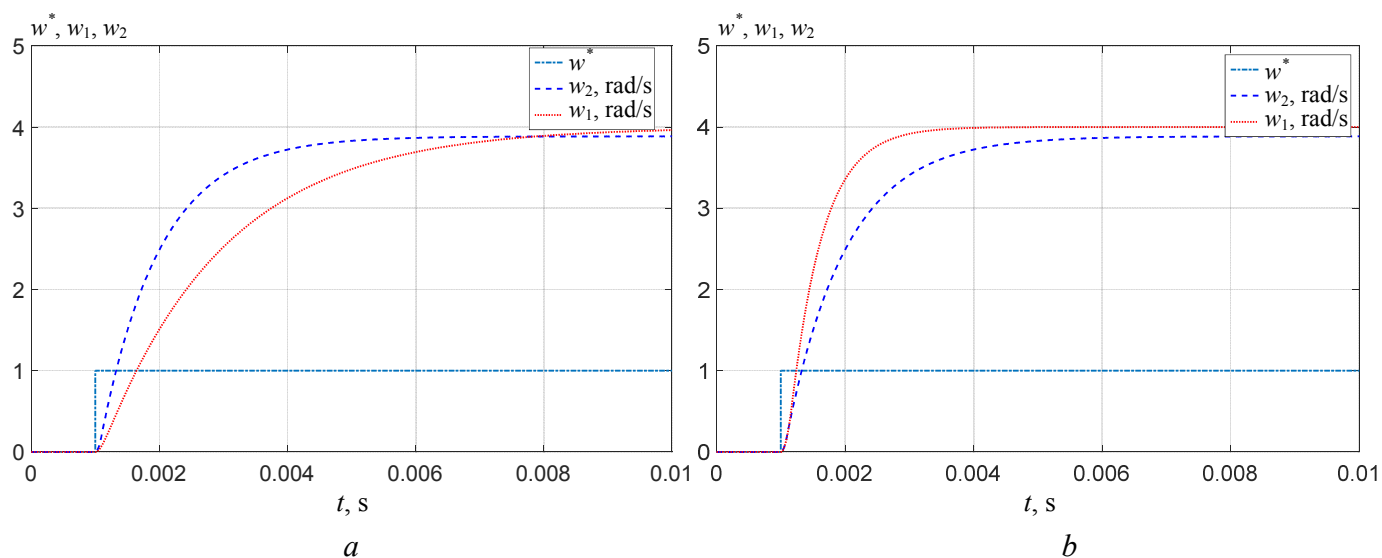

Fig. 5. Results of simulation of transients of systems with a jump in the reference signal

The results of modeling the transients of systems when generating a reference signal in the form of rectangular pulses with a duration of $t_{i m p}=5 \mathrm{~ms}$ with a pulse repetition rate of $100 \mathrm{~Hz}$ are shown in Fig. 6. Formation of the speed reference signal $\omega *$ in the form of rectangular pulses for the simulation conditions shown in Fig. 6, $a$, provides a movement $L_{1}$ of the wire (Fig. 6,b) by $3 \mathrm{~mm}$ with aperiodic adjustment of the loop using the CIPD. In the system with the P-controller of the speed loop, the movement $L_{2}$ of the wire (Fig. 6,b) was only $1.8 \mathrm{~mm}$. The simulation results showed that with a load surge from 0 to $5 \mathrm{Nm}$ for a $4 \mathrm{~ms}$ pulse and a pulse

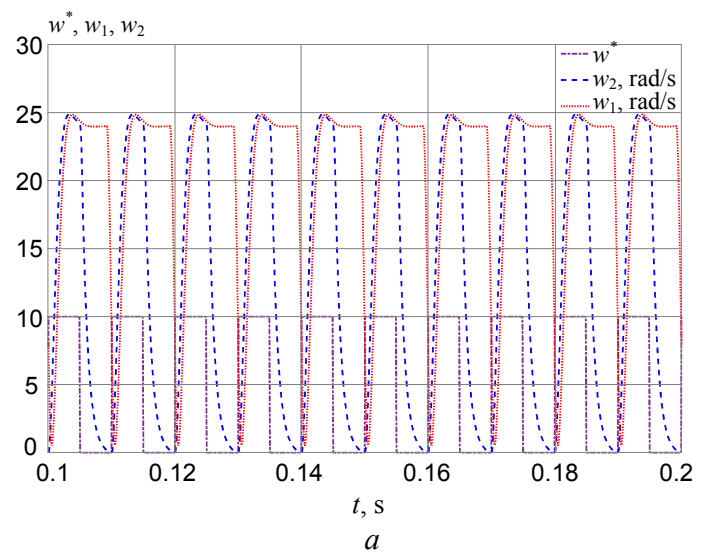

Fig. 6. Results of simulation of transients of systems with a reference signal in the form of rectangular pulses

Conclusions.

1. The results of the study of the system with the proposed speed controller shown that the electrode wire feed mechanism provides the required linear movement with a reference signal in the form of rectangular pulses at a repetition rate of $100 \mathrm{~Hz}$. The recommended pulse width of the speed reference should not exceed $5 \mathrm{~ms}$.

2. Studies of the system have also shown that at certain ratios of parameters, the speed P-controller can ensure the development of the required movements at a pulse repetition rate of $100 \mathrm{~Hz}$, but with inferior quality indicators. Taking into account the possible range of variation of the system parameters, the final choice of the type of controller and the method of its adjustment should be determined by the technological requirements for the quality indicators of the ACS. repetition rate of $100 \mathrm{~Hz}$, the wire displacement $L_{1}$ per pulse varied from $2.64 \mathrm{~mm}$ to $2.35 \mathrm{~mm}$. The movement $L_{2}$ of the wire in the automatic control system with a speed P-controller for the same conditions of changing the load was less than $1.4 \mathrm{~mm}$. When increase in the pulse time in the system with the speed P-controller up to $8 \mathrm{~ms}$, the wire movement $L_{2}$ per pulse was changed from $2.2 \mathrm{~mm}$ to $2.8 \mathrm{~mm}$ with a decrease in the load in the range from $5 \mathrm{Nm}$ to zero. Reducing the value of the moment of inertia $J$ by 2 times allows with a load of $5 \mathrm{Nm}$ and duration of pulse of $5 \mathrm{~ms}$ to ensure the wire movement $L_{1}$ by $2.4 \mathrm{~mm}$.

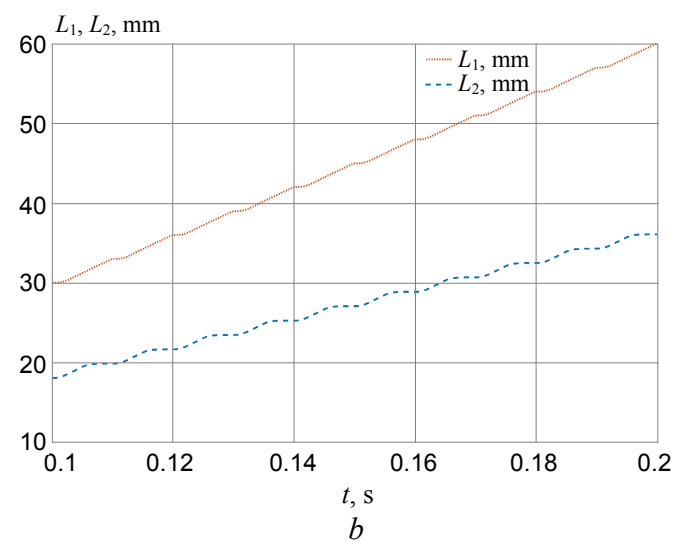

\section{REFERENCES}

1. Paton B.E. Modern directions of research and development in the field of welding and structural strength. Automatic welding, 2003, no. 10, 11 (607), pp. 7-13. (Rus).

2. Makovetskaya O.K. Main trends in the welding equipment market in 2008-2011 and forecast of its development (Review). Automatic welding, 2012, no. 6, pp. 44-50. (Rus).

3. Pal K., Pal S.K. Effect of Pulse Parameters on Weld Quality in Pulsed Gas Metal Arc Welding: A Review. Journal of Materials Engineering and Performance, 2010, vol. 20, no. 6, pp. 918-931. doi: 10.1007/s11665-010-9717-y.

4. Harris I. Transfer of heat and mass to the base metal in gas metal arc welding. Welding, Brazing, and Soldering, 2011, vol. 6, pp. 82-88.

5. Paton B.E., Lebedev V.A., Pichak V.H., Poloskov S.I., Shchavelev L.N. Analysis of technical and technological possibilities of the pulsed feed of electrode wire in arc welding and surfacing processes. Welding International, 2002, vol. 16, no. 7 , pp. 575-581. doi: $\mathbf{1 0 . 1 0 8 0 / 0 9 5 0 7 1 1 0 2 0 9 5 4 9 5 8 0 . ~}$ 
6. Krampit N.Y. Methods of controlling melting and transfer of electrode metal (review). Welding International, 2010, vol. 24 , no. 10, pp. 808-812. doi: 10.1080/09507116.2010.486194.

7. Paton B.E., Lebedev V.A., Zhuk G.V., Dragan S.V. Mechanical impulse and vibration effects in equipment and technologies of mechanized welding and surfacing. 16th International Science and Technology Conference «Vibrations in technology and technology». Collection of theses. Vinnytsia, Ukraine, 26-27 October 2017, pp. 10-16. (Rus).

8. Lebedev V., Reisgen U., Lendiel I. Study of technological opportunities of GMA welding and surfacing with pulse electrode wire feed. Welding in the World, 2016, vol. 60, no. 3, pp. 525-533. doi: 10.1007/s40194-016-0321-0.

9. Lebedev V.A., Rymsha V.V., Radimov I.N. Modern valve electric drives in systems of mechanized welding equipment Electrical machine-building and electrical equipment, 2009, no. 74, pp. 22-24. (Rus).

10. Lebedev V.A., Dragan S.V., Zhuk G.V., Novikov S.V., Simutenkov I.V. Application of pulsed impact in consumable electrode gas-shielded arc welding (Review). The Paton Welding Journal, 2019, no. 8, pp. 18-26. doi: 10.15407/tpwj2019.08.04.

11. Gill J.S., Kalyan Reddy T. Effect of weld pool vibration on fatigue strength and tensile strength of stainless-steel buttwelded joints by GTAW process. Proceedings of the World Congress on Engineering, 2018, vol. II WCE 2018, July 4-6, 2018, London, U.K.

12. Kuznetsov B.I., Nikitina T.B., Bovdui I.V., Kobilyanskiy B.B. Improving of electromechanical stabilization systems accuracy. Electrical engineering \& electromechanics, 2019, no. 2, pp. 21-27. doi: 10.20998/2074-272X.2019.2.04.

13. Kuznetsov B.I., Nikitina T.B., Kolomiets V.V., Bovdui I.V. Improving of electromechanical servo systems accuracy. Electrical engineering \& electromechanics, 2018, no. 6, pp. 3337. doi: 10.20998/2074-272X.2018.6.04.
14. Ostroverkhov M., Pyzhov V. Korol S. Control of the electric drive under conditions of parametric uncertainty and coordinates' interrelation. 2017 International Conference on Modern Electrical and Energy Systems (MEES), Kremenchuk, 2017, pp. 64-67. doi: 10.1109/MEES.2017.8248953.

15. Terekhov V.M., Osipov O.I. Sistemy upravleniia elektroprivodov. Uchebnik dlia studentov vysshikh uchebnykh zavedenii [Control systems of electric drives. Textbook for students of higher educational institutions]. Moscow, Akademiia Publ., 2006. 304 p. (Rus).

16. Lebedev V.A., Guly M.V. The high-speed valve electric drive for the equipment of the mechanized arc welding. Mechatronics, automation, control, 2014, no. 6. pp. 47-51. (Rus).

Received 09.09.2020

Accepted 16.10.2020

Published 24.12.2020

V.A. Lebedev ${ }^{1}$, Doctor of Technical Science, Professor,

G.V. Zhuk,

N.J. Ostroverkhov ${ }^{2}$, Doctor of Technical Science, Professor,

A.M. Khalimovskyy ${ }^{2}$, Candidate of Technical Science, Associate

Professor,

${ }^{1} \mathrm{SF}$ «Experimental Design-Technological Office

of the E.O. Paton Electric Welding Institute

of the National Academy of Sciences of Ukraine»,

7, Bogenko Str., Kiev, 03150, Ukraine,

e-mail: valpaton@ukr.net, oktb-paton@i.ua

${ }^{2}$ National Technical University of Ukraine «Igor Sikorsky Kyiv Polytechnic Institute»,

37, Prospect Peremohy, Kyiv-56, 03056, Ukraine,

e-mail: n.ostroverkhov@hotmail.com,o.khalimovskyy@ukr.net

How to cite this article:

Lebedev V.A., Zhuk G.V., Ostroverkhov N.J., Khalimovskyy A.M. Control of valve electric drive coordinates of automated welding equipment feed mechanisms. Electrical engineering \& electromechanics, 2020, no. 6, pp. $24-29$. doi: 10.20998/2074-272X.2020.6.04. 